\title{
ANALISIS YURIDIS KONTRAK PENGADAAN BARANG SIMULATOR SURAT IZIN MENGEMUDI POLRI
}

\section{JURIDIS ANALYSIS RELATED TO A GOOD PROCUREMENT CONTRACTS OF SIMULATOR DRIVING LICENSE POLRI}

\author{
Yulita Heriyanti dan \\ Martin Roestamy
}

\author{
Program Studi Ilmu Hukum Sekolah Pascasarjana \\ Universitas Djuanda Bogor \\ Jl. Tol Ciawi No. 1, Kotak Pos 35, Bogor 16720. \\ Korespondensi : Yulita Heriyanti, Telp. - \\ e-mail :
}

Jurnal Living Law, Vol. 10, No. 1 , 2018

hlm. 1-10

\begin{abstract}
In the case of the procurement of simulators Driving License, there are some deviations made by almost all parties involved to cause state losses. The identification of this research included the implementation of SIM simulators in the Traffic Corps of the National Police, the criminal elements that occurred and their weak points, as well as their positive and negative forms in the implementation of SIM simulator procurement. The research method used in this study is a normative juridical approach using library studies. The results of this study are: 1) There has been a standard agreement between the two parties that is not balanced in the procurement of SIM Simulator goods, where PT. X as the supplier of goods does not get an offer from the formulation of the agreement; 2) In the implementation of SIM Simulator goods procurement, the agreement between the two parties is not balanced and this becomes a weakness that can complicate the position of PT. X because it is in a weak position even though the terms of the agreement made by the National Police Corruption Eradication Agency provide an opportunity for contractors to determine and design contracts as they already are; 3) procurement carried out using the public auction method with third parties is considered effective and efficient in using the budget. But the negative thing is the existence of irregularities committed by partners with unscrupulous officials.
\end{abstract}

Keywords : Procurement Contracts, Driving License Simulator, POLRI

\begin{abstract}
Abstrak : Dalam kasus pengadaan simulator Surat Izin Mengemudi (SIM) terdapat beberapa penyimpangan yang dilakukan oleh hampir semua pihak yang terlibat hingga mengakibatkan kerugian negara. Identifikasi penelitian ini mencakup Pelaksanaan pengadaan simulator SIM di Korps Lalu Lintas Polri,unsur pidana yang terjadi dan titik lemahnya, serta bentuk positif dan negatifnya dalam pelaksanaan pengadaan simulator SIM. Metode penelitian yang digunakan dalam penelitian ini adalah pendekatan yuridis normatif menggunakan studi kepustakaan. Hasil dari penelitian ini yaitu: 1) Telah terjadi perjanjian baku antara kedua belah pihak yang tidak seimbang dalam pengadaan barang Simulator SIM, dimana PT. X selaku penyedia barang tidak mendapat penawaran dari perumusan perjanjian tersebut; 2) Dalam pelaksanaan pengadaan barang Simulator SIM, perjanjian kedua belah pihak tidak seimbang dan ini menjadi kelemahan yang dapat mempersulit posisi PT. X karena berada di posisi yang lemah walaupun syaratnya perjanjian yan dibuat oleh Korlantas Polri memberi peluang kepada kontraktor untuk menentukan dan merancang kontrak sebagaimana yang telah ada; 3) pengadaan yang dilakukan dengan metode pelelangan umum dengan pihak ketiga dinilai efektif dan efisien dalam penggunaan anggaran. Namun hal negatifnya yaitu adanya penyimpangan yang dilakukan oleh rekanan dengan oknum pejabat.
\end{abstract}

Kata Kunci : Kontrak Pengadaan, Simulator SIM, POLRI 


\section{PENDAHULUAN}

Pembangunan nasional yang dilaksanakan oleh bangsa Indonesia saat ini merupakan pembangunan berkesinambungan secara bertahap guna meneruskan cita-cita bangsa untuk mewujudkan peningkatan kesejahteraan masyarakat dalam rangka tercapainya tujuan masyarakat adil dan makmur berdasarkan Pancasila dan UUD 1945. Di era globalisasi ini, pembangunan tersebut dilaksanakan secara terpadu dan terencana di segala sektor kehidupan. Pembangunan adalah usaha untuk menciptakan kemakmuran dan kesejahteraan rakyat, oleh karena itu hasil-hasil pembangunan harus dapat dinikmati seluruh rakyat dalam bentuk peningkatan kesejahteraan lahir dan batin secara adil dan merata. Berhasilnya pembangunan tergantung partisipasi rakyat yang berarti pembangunan harus dilaksanakan secara merata oleh segenap lapisan masyarakat. ${ }^{1}$

Kepolisian merupakan salah satu lembaga pemerintahan yang memberikan pelayanan kepada masyarakat. Fungsi pemerintahan yang dijalankan oleh Polri terutama yang bersangkutan dengan penegakan hukum, pengayoman, perlindungan, pelayanan pembimbingan kepada masyarakat, tugas-tugas ini berkaitan erat dengan tugas-tugas sosial yang sehari-harinya berhadapan dengan masyarakat. Di dalam menjalankan tugasnya kepolisian menjalankan kegiatan pencegahan (preventif) dan penegakan hukum (reprensif).

Pelayanan Surat Izin Mengemudi (SIM) merupakan salah satu pelayanan dasar administratif yang penting. Dengan SIM, seseorang dianggap sudah memiliki hak dan kewajiban dalam mengendarai kendaran bermotor. Dengan adanya SIM, seseorang telah dianggap menjadi suatu wajib hukum yang taat hukum, sehingga dalam berkendara haruslah selalu mentaati peraturan yang berlaku, SIM merupakan

${ }^{1}$ F.X. Djumialdi, Perjanjian Pemborongan, Jakarta: Bina Aksara, 1987, Hlm. 1. bukti administratif bahwa seseorang tersebut sudah terikat oleh hukum, terutama hukum dalam berkendaraan.

Dalam Peraturan Kepala Kepolisian Negara Republik Indonesia Nomor 9 Tahun 2012 tentang Surat Izin Mengemudi. Pasal 1 angka 4, menyatakan Surat Izin Mengemudi yang selanjutnya disingkat SIM adalah tanda bukti legitimasi kompetensi, alat kontrol, dan data forensik kepolisian bagi seseorang yang telah lulus uji pengetahuan, kemampuan, dan keterampilan untuk mengemudikan Ranmor di jalan sesuai dengan persyaratan yang ditentukan berdasarkan UndangUndang Lalu Lintas dan Angkutan Jalan. Selanjutnya dalam Pasal 52 ayat (2), menyebutkan bahwa yang berwenang dalam melakukan penerbitan Surat Izin Mengemudi (SIM) kepada masyarakat adalah Kepala Kepolisian di setiap wilayah masing-masing dan didelegasikan kepada Kepala Satuan Lalu Lintas.

Perjanjian pengadaan barang dan jasa sering dibuat dalam bentuk kontrak standar, dimana suatu kontrak telah dipersiapkan terlebih dahulu oleh salah satu pihak dan pihak yang lainnya hanya dihadapkan pada pilihan untuk menerima atau menolak perjanjian tersebut. Perjanjian baku atau standar lahir sebagai bentuk dari perkembangan dan tuntutan dunia usaha. Kontrak standar telah banyak diterapkan dalam dunia usaha seperti perbankan, lembaga pembiayaan konsumen, dan berbagai bentuk usaha lainya. Kontrak standar atau baku dipandang lebih efisien dari sisi waktu dan biaya. $^{2}$ Secara formal di Indonesia aturan hukum mengenai perjanjian baku atau standar belum diatur dengan jelas, sehingga perlu mendapatkan kajian lebih lanjut. Hukum pada dasarnya adalah untuk perlindungan kepentingan manusia. Dalam setiap hubungan hukum, termasuk perjanjian harus ada keseimbangan antara para pihak supaya tidak terjadi konflik

2 Munir Fuady, Hukum Kontrak (Dari Sudut Pandang HukumBisnis), Bandung: PT Citra Aditya Bakti, 2003, Hlm. 10. 
kepentingan. Namun dalam realitasnya tidak selalu demikian. Selalu terdapat kemungkinan salah satu pihak mempunyai posisi yang lebih kuat baik dari sisi ekonomis maupun dari penguasaan teknologi atau suatu penemuan yang spesifik. Dalam kondisi ini salah satu pihak lebih mempunyai peluang untuk lebih diuntungkan dalam suatu perjanjian.

Dalam suatu kontrak yang telah disepakati tentunya ada hal-hal yang ingin dicapai sesuai dengan kesepakatan para pihak, namun dalam pelaksanaanya, hal-hal yang sudah diatur dan disepakati tidak senantiasa dapat berjalan dengan baik. Hal ini juga dapat terjadi dalam kontrak pengadaan yang dilakukan oleh pemerintah dengan pihak penyedia barang/jasa, seperti perbuatan wanprestasi atas keterlambatan waktu penyelesaiannya, yang atas perbuatan wanprestasi tersebut menimbulkan kerugian pada pihak pemberi kerja. Wanprestasi adalah tidak memenuhi atau lalai melaksanakan kewajiban sebagaimana yang ditentukan dalam perjanjian yang dibuat antara kreditur dengan debitur. ${ }^{3}$

Dalam kasus pengadaan simulator Surat Izin Mengemudi (SIM) terdapat beberapa penyimpangan yang mengakibatkan kerugian negara sebesar Rp 121 miliar. Penyimpangan ini dilakukan oleh hampir semua pihak yang terlibat dalam proyek dengan nilai kontrak Rp 169 miliar tersebut. Penyimpangan itu dilakukan oleh berbagai pihak mulai level Kuasa Pengguna Anggaran (KPA), Pejabat Pembuat Komitmen (PPK), hingga panitia pengadaan.

Berdasarkan uraian latar belakang masalah tersebut di atas, maka identifikasi masalah yang akan dibahas dalam penelitian ini adalah:

1. Bagaimana pelaksanaan pengadaan barang dan jasa simulator Surat Izin Mengemudi di Korps Lalu Lintas Polri?

\footnotetext{
3 Soesila Prayogo, Kamus Hukum Internasional \& Indonesia, Jakarta: Penerbit Wipress, 2007, Hlm. 501.
}

2. Mengapa dalam pelaksanaan pengadaan simulator Surat Izin Mengemudi terjadi perbuatan pidana, dimana letak titik lemahnya?

3. Bagaimana bentuk positif dan negatifnya dalam pelaksanaan pengadaan simulator Surat Izin Mengemudi?

\section{METODE PENELITIAN}

Metode penelitian yang digunakan dalam penelitian ini adalah pendekatan yuridis normatif, yaitu hukum dikonsepsikan sebagai norma, kaidah, asas atau dogma-dogma/yurisprudensi. Tahap penelitian yuridis normatif, menggunakan studi kepustakaan (penelaahan terhadap literatur). Dalam penelitian ini bahan pustaka merupakan data dasar penelitian yang digolongkan sebagai data sekunder.

\section{PEMBAHASAN}

\section{A. PELAKSANAAN PENGADAAN BARANG DAN JASA SIMULATOR SURAT IZIN MENGEMUDI DI KORPS LALU LINTAS POLRI}

Dalam pengadaan Simulator Surat Izin Mengemudi (SIM) terdapat beberapa aspek menurut penulis yang harus diperhatikan Korlantas Polri khususnya panitia pengadaan Simulator Surat Izin Mengemudi (SIM), yaitu:

1. Berpijak pada prinsip-prinsip terbuka dan bersaing;

2. Akuntabel dan didasarkan kepentingan masyarakat umum;

3. Korlantas Polri melalui panitia pengadaan Simulator Surat Izin Mengemudi (SIM) perlu mempertimbangkan jenis, sifat, nilai jasa, kondisi lokasi, kepentingan masyarakat dan jumlah kontraktor yang ada;

4. Menetapkan kriteria dan persyaratan pengadaan jasa yang obyektif dan tidak diskriminatif;

5. Melaksanakan penetapan pengadaan barang secara transparan dan adil untuk menghindari terbukanya 
kemungkinan Korupsi, Kolusi dan Nepolitisme (KKN) dalam pelaksanaannya.

Dilihat dari ketentuan-ketentuan yang terkait dengan perjanjian pengadaan barang dan jasa adalah merupakan perjanjian, yaitu: hubungan yang terjadi antara pengguna barang dan jasa dan penyedia barang dan jasa adalah hubungan hukum untuk melakukan suatu pekerjaan tertentu bagi pengguna barang dan jasa dan sebagai kompensasinya penyedia barang dan jasa mendapatkan sejumlah pembayaran yang telah ditetapkan (Pasal 1601 KUHPerdata).

Seperti perjanjian pada umumnya maka perjanjian juga mengandung prinsipprinsip Hukum Perikatan yang tercantum dalam KUHPerdata, yaitu:

1. Memenuhi syarat-syarat sahnya suatu perjanjian (Pasal 1320);

2. Semua perjanjian yang dibuat secara sah berlaku sebagai undang-undang bagi yang membuatnya dan harus dilaksanakan dengan itikad baik (Pasal 1338);

3. Perjanjian hanya berlaku antara para pihak yang membuatnya (Pasal 1340).

Dari hasil penelitian terhadap dokumen Perjanjian Pengadaan Barang dan Jasa di Korlantas Polri merupakan dasar dari pelaksanaan kerja dapat diketahui bahwa perjanjian pengadaan barang dan jasa harus dibuat dalam bentuk tertulis, namun tidak dijelaskan lebih lanjut mengenai apakah perjanjian tersebut dibuat dalam bentuk otentik atau perjanjian di bawah tangan.

Dalam praktek perjanjian pengadaan barang dan jasa dibuat dalam bentuk akta di bawah tangan bukan dalam bentuk otentik (akta notariil). Dimana draft perjanjian telah dipersiapkan terlebih dahulu oleh pihak pengguna jasa dalam hal ini oleh Korlantas Polri. Dibuatnya perjanjian pengadaan barang dan jasa tersebut dalam bentuk akta di bawah tangan didasarkan oleh efesiensi waktu dan biaya. Dalam merancang perjanjian panitia pengadaan barang dan jasa di lingkungan Korlantas Polri menggunakan standar kontrak atau contoh Surat Perjanjian Kerja (SPK).

Hal-hal yang menyangkut pelaksanaan perjanjian pengadaan barang dan jasa merupakan ketentuan standar yang telah ditetapkan oleh Korlantas Polri sebagai pengguna jasa. Langkah ini dilakukan dengan tujuan untuk menciptakan syarat dan kondisi yang sama dalam setiap perjanjian pengadaan barang dan jasa kepada setiap penyedia jasa.

Sehingga tidak terdapat diskriminasi perlakuan syarat dan kondisi dalam perjanjian pengadaan barang dan jasa yang harus dipatuhi oleh pihak rekanan. Setiap kontrak pengadaan barang dan jasa dibuat terdiri dari 2 (dua) rangkap yang sama isi dan kekuatan hukumnya, masing-masing bermeterai cukup dan ditanda tangani oleh para pihak terkait.

Dari perjanjian pengadaan barang dan jasa tersebut di atas dapat disimpulkan pihak kontraktor tinggal menandatangani perjanjian tersebut tanpa negosiasi yang berarti. Sehingga prinsip "taked or lived" yang biasa terjadi dalam suatu perjanjian standar berlaku juga terhadap perjanjian pengadaan barang dan jasa, perjanjian pengadaan barang dan jasa merupakan perjanjian baku dan pihak kontraktor mempunyai hak untuk ikut serta dalam merumuskan perjanjian.

Pihak kontraktor cendrung mengabaikan mekanisme perancangan kontrak, isi kontrak dan akibat-akibat hukumnya. Hal ini dapat diketahui berdasarkan hasil penelitian lapangan, pihak kontraktor hanya berorientasi kepada proyek dalam arti kontraktor hanya mempunyai target menjadi pemenang tender, sedangkan permasalahan kontrak pengadaan barang dan jasa yang akan ditandatangani dalam setiap proyek yang diperolehnya dilakukan tanpa negosiasi lebih lanjut. Hal ini merupakan indikator lemahnya posisi tawar pihak kontraktor dalam pembuatan perjanjian pengadaan barang dan jasa. 


\section{B. PELAKSANAAN \\ PENGADAAN SIMULATOR SURAT IZIN MENGEMUDI TERJADI PERBUATAN PIDANA, DIMANA LETAK TITIK LEMAHNYA}

Dalam Peraturan Presiden Nomor 4 Tahun 2015 tentang Pengadaan Barang/Jasa Pemerintah diatur mengenai perilaku menyimpang yang dapat dikenai sanksi yaitu Penyedia Barang/Jasa, Unit Layanan Pengadaan (ULP) serta Pejabat Pembuat Komitmen (PPK). Perbuatanperbuatan yang diancam dengan sanksi dirumuskan di dalam Pasal 118. Berdasarkan aturan ini, maka perbuatanperbuatan yang dapat diproses secara pidana yakni apabila penyedia barang/jasa:

1. Berusaha mempengaruhi kelompok kerja ULP/Pejabat Pengadaan/pihak lain yang berwenang dalam bentuk dan cara apapun, baik langsung maupun tidak langsung guna memenuhi keinginannya yang bertentangan dengan ketntuan dan prosedur yang telah ditetapkan dalam Dokumen Pengadaan/Kontrak dan/atau ketentuan peraturan perundangundangan.

2. Melakukan persekongkolan dengan penyedia barang/jasa lain untuk mengatur harga penawaran di luar prosedur pelaksanaan pengadaaan barang/jasa sehingga mengurangi, menghambat, memperkecil dan/atau peniadakan persaingan yang sehat dan/atau merugikan orang lain.

3. Membuat dan/atau menyampaikan dokumen dan/atau keterangan lain yang tidak benar untuk memenuhi persyaratan pengadaan barang/jasa yang ditentukan dalam dokumen pengadaan.

4. Mengundurkan diri setalah batas akhir pemasukan penawaran atau mengundurkan diri dari pelaksanaan kontrak dengan alasan tidak dapat dipertanggung jawabkan dan/atau tidak diterima oleh kelompok kerja ULP/Pejabat Pengadaan.
5. Tidak dapat menyelesaikan pekerjaan sesuai dengan kontrak secara bertanggung jawab.

6. Berdasarkan hasil pemeriksaan sebagaimana dalam Pasal 99 ayat (3) ditemukan danya ketidak sesuaian dalam pengunaan barang/jasa produk dalam negeri.

Berdasarkan ketentuan Pasal 118 Perpres No. 4 Tahun 2015, apabila terjadi penyimpangan sebagaimana disebutkan di atas, maka dimungkinkan untuk diproses secara pidana tetapi tidak penjelasan lebih lanjut peraturan hukum pidana apa yang digunakan untuk menghukum pelaku penyimpangan tersebut. Oleh karena itu apabila terjadi penyimpangan sebagaimana tersebut di atas yang dilakukan oleh penyedia barang/jasa, maka dimungkinkan untuk menggunakan peraturan hukum pidana mana saja yang tepat untuk diterapkan seperti Kitab Undang-undang Hukum Pidana, Undang-Undang Tindak Pidana Korupsi dan yang lainnya, hal ini tergantung terhadap penyimpangnnya.

Dalam hal terjadi penyimpangan sebagaimana yang disebutkan di atas, maka dapat juga dijatuhi sanksi administrasi yang pemberian sanksinya dilakukan oleh PPK/kelompok kerja UPL/Pejabat Pengadaan. Sedangkan pemberian sanksi berupa pencantuman daftar hitam dilakukan oleh PA/KPA setelah mendapatkan masukan dari PPK/kelompok kerja ULP/Pejabat Pengadaan sesuai dengan ketentuan. Terhadap penyimpangan tersebut di atas, apabila ingin dituntut secara perdata ataupun melalui jalur pidana, maka dilakukan sesuai dengan peraturan perudang-undangan. Hal ini telah sesuai dengan isi Pasal 118 Perpres No. 4 Tahun 2015.

Apabila ditemukan penipuan atau pemalsuan atas informasi yang disampaikan penyedia barang/jasa, terhadap penyedia barang/jasa dapat dikenakan sanksi berupa pembatalan sebagai calon pemenang, dimasukkan ke dalam daftar hitam, dan jaminan pengadaan barang/jasa dicairkan dan 
disetorkan ke kas negara/daerah dan hal ini telah sesuai dengan rumusan Pasal 118 ayat (6) Perpres No. 4 Tahun 2015. Kemudian selain menjatuhkan sanksi terhadap perbuatan atau tindakan penyidia barang/jasa sebagaimana dimaksud dalam Pasal 118 ayat (1), terhadap penyedia barang/jasa dapat juga dikenakan denda keterlambatan yaitu dalam hal penyedia barang/jasa terlambat menyelesaikan pekerjaan dalam jangka waktu sebagaimana ditetapkan dalam kontrak karena kesalahan penyedia barang/jasa.

Terkait dengan ULP sesuai dengan Pasal 123 Perpres No. 4 Tahun 2015, bahwa dalam hal terjadi kecurangan dalam pengumuman pengadaan, sanksi diberikan kepada anggota ULP/Pejabat Pengadaan sesuai dengan peraturan perundangundangan. Selanjutnya menurut 118 ayat (7), apabila terjadi pelanggaran dan/atau kecurangan dalam proses pengadaan barang/jasa, maka Unit Layanan Pengadaan (ULK):

a. Dikenakan sanksi administrasi;

b. Dituntut ganti rugi dan/atau;

c. Dilaporkan secara pidana.

Sesuai dengan Pasal 119 Perpres No. 4 Tahun 2015, maka perbuatan atau tindakan sebagaimana dimaksud dalam Pasal 118 ayat (1) huruf f selain dikenakan sanksi sebagaimana dimaksud dalam Pasal 118 ayat (2) huruf a dan huruf b, dikenakan sanksi finansial, berarti, dalam hal ini ada penerapan sanksi kumulatif karena selain dikenakan sanksi administrasi, pencantuman dalam daftar hitam, gugatan secara perdata, pelaporan secara pidana kepada pihak yang berwenang, maka dimungkinkan untuk dijatuhi sanksi secara finansial.

Dalam Perpres No. 4 Tahun 2015 ditentukan juga jenis-jenis sanksi lain selain yang telah diuraikan di atas, yaitu berupa keharusan menyusun kembali perencanaan dengan beban biaya dari konsultan yang bersangkutan, ganti rugi, kompensasi serta dimasukkan ke dalam daftar hitam.
Dalam kasus pengadaan Simulator Surat Izin Mengemudi (SIM) menurut Badan Pemeriksan Keuangan (BPK) terdapat beberapa penyimpangan yang merugikan negeri Rp. 121 miliar. Menurut Auditor BPK AES, ${ }^{4}$ dimulai sejak proses penganggaran hingga pembayaran. BPK menemukan, dilibatkannya PT. X dan PT. Y, dua perusahaan yang menjadi kontraktor proyek simulator pada tahap pengagaran. Dua perusahaan itu dipastikan jadi pemenang sebelum proses tender dimulai. Bahkan data-data yang digunakan dalam proses penggaran adalah data-data pihak PT. $X$ dan $Y$ sehingga terjadi konflik kepentingan.

Jadi titik lemah pengadaan Simulator Surat Izin Mengemudi (SIM) antara lain:

1. Tahap perencanaan pengadaan, dengan cara mark up atau penggelembungan anggaran sebesar Rp 100 miliar dari total nilai kontrak Rp 169 miliar.

2. Tahap penyerahan barang, kerugian juga bersumber dari ketidaksesuaian spesifikasi barang dengan perjanjian yang tertera dalam kontrak senilai $\mathrm{Rp}$ 21 miliar. Berdasar cek fisik simulator Roda dua (R 2) dan Roda empat (R 4) di 272 titik yang tersebar di 33 provinsi ditemukan spesifikasi yang tidak sesuai dengan kontrak, bahkan ada banyak alat yang tidak berfungsi. Dari angka Rp 21 miliar kerugian yang bersumber dari ketidaksesuaian spesifikasi, simulator roda empat menyumbang kerugian $\mathrm{Rp} 10$ miliar dan sisanya Rp 11 miliar berasal dari roda empat. Untuk mark up anggaran sebesar $\mathrm{Rp} 86$ miliar dilakukan di simulator roda empat dan Rp 14 miliar di roda dua. Sehingga total penggelembungan Rp 100 miliar.

3. Penyusunan Harga Perkiraan Sendiri (HPS), Direktur Y, SSB, turut berperan dalam menyiapkan perusahaan pendamping dalam proses lelang. Ia juga membantu panitia pengadaan dalam membuat spesifikasi teknis dan

\footnotetext{
4 Hasil wawancara dengan AES selaku Auditor BPK, pada tanggal 21 Februari 2017.
} 
Harga Perkiraan Sendiri (HPS). Dalam penyusunan HPS itu terjadi penggelembungan harga (mark up). Caranya dengan menuliskan komponen utuh dan kemudian merinci bagian komponen itu, memasukkan komponen yang tidak digunakan, serta menaikan harga masing-masing komponen.

4. Tahap lelang, dalam pelaksanaan pengadaan driving simulator uji klinik, DS telah melanggar ketentuan dengan menyetujui pencairan anggaran seratus persen untuk PT. X. DS telah menyampaikan arahan kepada ketua panitia pengadaan, TS, untuk memberikan pekerjaan pada BS. BS merupakan Direktur PT. X. Perbuatan DS yang telah memerintahkan ketua panitia untuk memberikan pekerjaan pada BS, bertentangan dengan ketentuan Peraturan Presiden Nomor 4 Tahun 2015 tentang Pengadaan Barang/Jasa Pemerintah.

\section{BENTUK POSITIF DAN NEGATIFNYA DALAM PELAKSANAAN PENGADAAN SIMULATOR SURAT IZIN MENGEMUDI}

Pengadaan barang/jasa pemerintah memiliki peran yang sangat penting dalam pelaksanaan Anggaran Pendapatan dan Belanja Negara (APBN). Hampir sebagian besar belanja pemerintah yang dialokasikan dalam APBN dilaksanakan melalui proses pengadaan barang/jasa, seperti belanja barang, belanja modal, sebagian belanja bantuan sosial dan belanja hibah. Belanja barang yang dialokasikan merupakan pengeluaran pemerintah dalam rangka pengadaan barang/jasa non investasi guna mendukung kegiatan operasional pemerintah.

Dalam Perpres Nomor 4 Tahun 2015 disebutkan bahwa pada dasarnya tujuan kebijakan umum pengadaan barang/jasa pemerintah adalah: (1) mensinergikan kegiatan ekonomi dari pengadaan barang/jasa pemerintah untuk mendorong percepatan tumbuhnya industri/jasa domestik; (2) pemerintah melaksanakan fungsinya sebagai pihak yang mendorong terjadinya pemerataan; (3) mendorong terjadinya multiplier effect yang lebih besar dari kegiatan pengadaan barang/jasa pemerintah, apabila seluruh industri/jasa domestik dapat dilibatkan secara optimal.

Kebijakan umum pemerintah dalam pengadaan barang/jasa adalah:

a. Meningkatkan penggunaan produksi dalam negeri.

Penggunaan produksi dalam negeri bertujuan meningkatkan perekonomian dalam negeri, sehingga kesejahteraan rakyat meningkat yang ditandai dengan peningkatan Gross National Product (GNP). Cara yang ditempuh melalui (1) memaksimalkan penggunaan produksi dalam negeri, (2) penggunaan SNI dalam spesifikasi teknis, (3) pembatasan keikutsertaan usaha asing, di atas 20 miliar untuk pengadaan barang, 100 miliar untuk jasa konstruksi, dan 10 miliar untuk jasa konsultansi, dan (4) preferensi harga untuk produksi dalam negeri.

b. Kebijakan kemandirian industri alat utama sistem pertahanan (alutsista) dan alat material khusus (almatsus) dalam negeri.

Kemandirian alutsista dan almatsus bertujuan untuk menghindari ketergantungan pada negara lain mengingat industri tersebut bersifat sangat strategis. Selain itu, produksi dalam negeri telah mampu menghasilkan sendiri produk alutsista dan almatsus dengan melibatkan anak bangsa.

c. Kebijakan peningkatan peran UMKM dan kelompok masyarakat.

Salah satu kebijakan pemerintah untuk menyejahterakan masyarakat adalah meningkatkan peran UMKM khususnya dalam pengadaan barang/jasa pemerintah. Cara yang ditempuh antara lain paket pekerjaan bernilai sampai dengan $\mathrm{Rp}$ 2,5 miliar untuk usaha kecil dan memperbanyak paket untuk usaha kecil. 
d. Kebijakan perhatian terhadap aspek pemanfaatan sumber daya alam dan pelestariannya.

Selama ini aspek pemanfaatan sumber daya alam dengan perhatian penuh pada pelestarian lingkungan kurang diperhatikan oleh pemerintah. Aspek tersebut dicantumkan dengan maksud untuk mendukung pembangunan berkelanjutan serta ikut serta dalam rangka mengurangi pengaruh rumah kaca dan pemanasan global.

e. Kebijakan peningkatan penggunaan teknologi informasi.

Penggunaan teknologi informasi yang berkembang semakin cepat dimaksudkan untuk mendukung prinsip pengadaan yaitu meningkatkan transparansi dan efisiensi tanpa campur tangan pihak-pihak yang berkepentingan.

f. Kebijakan penyederhanaan proses.

Selama ini proses pengadaan barang/jasa masih banyak sekadar memenuhi kewajiban administratif tanpa memperdulikan aspek substantifnya, akibatnya timbul biaya ekonomi tinggi dalam proses tersebut. Oleh karena itu kebijakan penyederhanaan proses pengadaan barang/jasa bertujuan untuk mengurangi biaya transaksi yang tidak perlu dalam rangka penerapan prinsip efisiensi dan efektivitas pengadaan. Cara yang ditempuh antara lain: (1) kualifikasi penyedia cukup dengan surat pernyataan, dan (2) sertifikat badan usaha tidak diperlukan.

g. Kebijakan profesionalisme para pihak. Pengadaan barang/jasa berperan sangat penting dalam penyelenggaraan pemerintahan dan rentan dengan penyimpangan, konsekuensinya pihakpihak terkait harus memiliki kompetensi dan profesional di bidangnya.

Sebagaimana yang diketahui, pengeluaran pemerintah dalam APBN adalah jumlah atau nominal yang terdiri dari beberapa rincian belanja, baik dilihat dari pembagian jenis fungsi dan belanja, maupun dari mekanisme di tahap pengalokasiannya. Anggaran Pengeluaran pemerintah ada yang dibelanjakan dalam bentuk cash atau ada juga melalui mekanisme pengadaan barang/jasa pemerintah dengan pelelangan umum atau seleksi sesuai peraturan yang berlaku..

\section{KESIMPULAN}

Berdasarkan hasil penelitian dan pembahasan yang telah penulis sampaikan di atas, maka sebagai penutup dapat ditarik kesimpulan sebagai berikut:

1. Telah terjadi perjanjian antara kedua belah pihak yang tidak seimbang dalam pengadaan barang Simulator Surat Izin Mengemudi, dimana PT. X selaku penyedia barang tidak mendapat penawaran dari perumusan perjanjian tersebut.

2. Dalam pelaksanaan pengadaan barang Simulator Surat Izin Mengemudi dalam melakukan perjanjiannya kedua belah pihak tidak seimbang dan ini menjadi kelemahan yang dapat mempersulit posisi PT. X selaku menyedia barang karena berada di posisi yang lemah walaupun syaratnya perjanjian yan dibuat oleh Korlantas Polri memberi peluang kepada kontraktor untuk menentukan dan merancang kontrak sebagaimana yang telah ada.

3. Bentuk positif dalam pelaksanaan pengadaan Simulator SIM yaitu, pengadaan barang dan jasa yang dilaksanakan dengan metode pelelangan umum dengan pihak ketiga dinilai efektif untuk mencegah adanya penyimpangan serta menjaga efektifitas dan efisiensi penggunaan anggaran. Sedangkan bentuk negatifnya yaitu dalam pengadaan barang/jasa pemerintah sering terjadinya penyimpangan yang dilakukan oleh rekanan sebagai pihak yang bertindak sebagai penyedia barang/jasa ataupun oknum pejabat yang bertindak sebagai pengguna barang/jasa. 
SARAN

1. Perlu peran serta aktif kedua belah pihak dalam perumusan perjanjian pengadaan barang/jasa agar perjanjian yang akan ditandatangani tersebut menjadi dasar pelaksanaan kerja yang memberikan perlindungan hukum kepada kedua belah pihak secara seimbang.

2. Perlunya pengawasan, pemeriksaan dan pengendalian dalam kegiatan pengadaan barang dan jasa baik secara internal maupun secara eksternal dengan melibatkan semua pihak, baik di eksekutif, legislatif maupun yudikatif.

3. Dalam pelaksanaan pengadaan barang/jasa pemerintah diperlukan suatu aturan yang lengkap dan rinci yang mengatur prosedur kerja sama dari proses pemilihan calon mitra sampai dengan pelaksanaan.

\section{UCAPAN TERIMA KASIH}

\section{DAFTAR PUSTAKA}

\section{Buku:}

Abdulkadir Muhammad, Hukum Perdata Indonesia, Bandung: PT. Citra Aditya Bakti, 2000.

F.X. Djumialdi, Perjanjian Pemborongan, Jakarta: Bina Aksara, 1987.

H. Purwosusilo, Aspek Hukum Pengadaan Barang dan Jasa, Jakarta: Prenadamedia Group, 2014.

Martin Roestamy, Dualisme Hukum Benda, Bogor: FH. Unida, 2007.

Munir Fuady, Hukum Kontrak (Dari Sudut Pandang Hukum Bisnis), Bandung: PT Citra Aditya Bakti, 2003.

Soesila Prayogo, Kamus Hukum Internasional \& Indonesia, Jakarta: Penerbit Wipress, 2007.

\section{Peraturan Perundang-undangan:}

Undang-Undang Nomor 2 Tahun 2002 tentang Kepolisian Negara Republik Indonesia.

Undang-Undang Nomor 17 Tahun 2003 tentang Keuangan Negara.

Peraturan Presiden Nomor 4 Tahun 2015 tentang Perubahan Keempat atas Peraturan Presiden Nomor 54 Tahun 2010 tentang Pengadaan Barang/Jasa Pemerintah.

Peraturan Kepala Kepolisian Negara Republik Indonesia Nomor 9 Tahun 2012 tentang Surat Izin Mengemudi. 


\section{Jurnal Hukum, Majalah:}

Majalah Tempo tanggal 29 April 2012, “Bimsalabim Simulator SIM.

Syahmin, AK, Mengkritisi Hukum Sebagai Sarana Pembaharuan Masyarakat Indonesia, Jurnal Hukum Progresif Volume I Nomor 2, Oktober, 2005. 